\title{
Management culture in Romania: Patterns of change and resistance $^{*}$
}

\author{
Kevin Dalton, Liz Kennedy**
}

This study examines how far restructuring has involved a change in leadership style and the development of new philosophies and approaches which derive from the Anglo-American model of 'people management'. During the Communist period, Romania experienced a highly centralised system of management. Broader currents of historical and political culture also served to inculcate values of bureaucratic formalism. In transitional times it appears that the management role is being re-defined and management culture is changing. This article seeks to understand these changes in the culture and identity of Romanian management by examining experience in a range of organisations. It also considers how far Anglo-American values of HRM and managing are relevant to a country where the wider cultural and historical experience differs so strikingly from that in the West.

Diese Studie überprüft, wie sehr die Restrukturierung den Führungsstil und die Entwicklung von neuen Philosophien und Ansätzen, die vom angloamerikanischen Modell des „People Management“ abgeleitet sind, beeinflußte. Während der Kommunistischen Periode besaß Rumänien ein stark zentralisiertes Managementsystem. Historische und politisch-kulturelle Einflüsse unterstützten die Entstehung und Festigung eines bürokratischen Formalismus. In der Übergangszeit erscheint es so, als ob Management neu definiert werde und die Managementkultur sich verändert. Dieser Artikel versucht diese Veräderugen in Kultur und Identität des Rumänischen Managements nachzuvollziehen und an einer Reihe von Organisationen zu überprüfen. Er untersucht zudem, wie stark anglo-amerikanische Werte des Human Recource Management und des Management relevant sind für ein Land dessen historische und kulturelle Erfahrung sich so auffallend deutlich von der des Westens unterscheidet.

Keywords: management, anglo - American model of HRM, leadership

\footnotetext{
Manuscript received: 25.11.06, accepted: 26.04.07 (1 revision)

Kevin Dalton, Senior Lecturer, University of Westminster. Main research areas: Organisational development, management development, culture, politics and change in organisations. Corresponding address: kgdalton@dalton86.fsnet.co.uk

Liz Kennedy, Senior Lecturer, University of Westminster. Main research areas: HRM strategies and systems, high performance, high commitment HR strategies, management development.
} 


\section{Introduction}

Since the fall of Communism, Romania has set out on the hard road of renewal to become a democratic market economy within a community of European nations. This is a road also travelled by other East European countries but few have had to start the journey from so far back or with the same weight of cultural baggage from the past. There is broad agreement across the ideological divide that Communist dictatorship in Romania flattened society and made initiative, critical thinking and innovation dangerous, yet these may be the qualities which management in a democratic market economy most needs. Here we look at how management culture in Romania seems to be adapting to new conditions and how far it is still influenced by the deadweight of history.

\section{The research study}

In this report we have focused on the compatibility of Western ideas concerning management style and behaviour and the dominant values of Romanian management culture. In particular we examine the following:

- How is Romanian management culture changing during the postCommunist period and how far does the historical legacy continue to exert an influence?

- How do societal assumptions impinge on management culture and the practice of management in Romania?

- Is there evidence of convergence towards an Anglo-American model of management and, if so, how appropriate is this model to the historical and cultural experience of Romania?

These are big themes relatively unexamined by research in cross cultural HR, but given sharp contemporary relevance by the recent accession of Romania to the EU. Timely diagnosis of existing cultural processes and the conditions under which 'best practice' seems to flourish may be useful for Romanian organisations attempting to become more competitive in world markets and Westerners wanting to do business in Romania.

\section{Research methods}

This research has evolved from the authors' involvement in teaching on a management development programme for middle and senior managers in Romania. Our students helped with contacts for our first sample of four multinationals and foreign owned organisations operating in Romania (Dalton 2006). Since then we have engaged in 'snowball sampling' by which organisational 'gatekeepers' have recommended others who might have a perspective relevant to our research. 
In this second phase of research we have tried to expand our sample to include Romanian organisations, both those which are still evolving from the mould of the old order and those which are actually embracing 'marketisation', as well as international organisations operating in Romania. We have also revisited our previous core of companies (12 organisations in total). These are the organisations in our sample:

- A large brewery which had been run by the state, now owned by a large international brewing company (BrewLite)in Bucharest.

- A large ball bearing company, now part of a foreign group (SteelCo)in Ploiesti.

- A medium sized supplier of security products now in foreign ownership (Securicare)in Lugoj.

- The foreign subsidiary of a transnational express delivery service (ExpressAir) in Bucharest.

- A joint owned software/ IT consultancy company (Softsolutions)in Bucharest.

- A Romanian owned IT consulting company (SoftCo)in Ploiesti

- A foreign owned trading and distribution company (TradeWinds)in Ploiesti

- A well known transnational manufacturer of soft drinks (SoftDrink)in Bucharest.

- A foreign owned clingfilm manufacturers with a plant in Romania (Clingfit)in Banat.

- An international charity (CharityHospital)in Transyvlania

- A regional water company under government ownership ie: a 'regie' or parastatal (KPA Canal) in Wallachia.

- A regional Social Services Department in the government sector (SocialCare)in Banat.

We have also spoken to academic specialists in the history and politics of Romania; business men, spokesmen of Romanian organisations living in the UK, the British-Romanian Chamber of Commerce, the British High Commissioner for Romania during part of the 90s and aproducer at the BBC World Service who gave us useful background and 'leads' for enquiry. Our fieldwork data has been collected from semi-structured interviews with businessmen, general managers, senior HR and functional managers. About 40 interviews were held, each of about one hour in length. The number of managers interviewed varied between organisations (between 3 and 12 in various locations), depending largely on who was interested in speaking to us. 
Although this imposes obvious limits to the representativeness of our findings, it is difficult to see how we might have otherwise proceeded in a society where access to people in power still seems to involve 'insider networks'.

The methodology we used was qualitative. We were less concerned with counting heads or collecting formal responses than with understanding informal processes and the interpretive sense making of others. We reflect this by including many direct quotations in the text which hopefully convey some of the rich textures of lived experience. To ensure some consistency in our collection of evidence we standardised the themes investigated across our research sites (Smith 1998). The research was carried out between June 2004- August 2006 and is planned to continue in the future. We hope to look at selected management issues in greater depth as well as testing our emergent findings in as broad a range of Romanian organisations as access allows. We would also like to trawl the experiences of operational managers and front line workers and we are hoping that we can extend our networks further in this direction. What is presented here is our interpretation of Romanian managerial behaviour embedded within its cultural context at a certain point in time.

\section{Anglo-American Management Model: Concept and application}

The organisations in our sample were differently positioned on a continuum of management cultures which seemed to range from 'authoritarian/bureaucratic' culture to a 'participative/flexible' or 'Incubator' culture (Trompenaars 1993)

However, with varying degrees of strategic intent, most of the organisations we surveyed were pursuing Western principles of management. Indeed, almost all were engaged in some form of management restructuring which involved a combination of the elements associated with the Anglo-American HR model (Brewster/Hegewisch 2000) and High Performance Work Practice model (Holbeche 2003; Huselid 1995). However, many critics (see Guest (1990) for a synopsis of the arguments) claim that these principles are not value neutral, but encode values which are part of the Western democratic and capitalist tradition.

We examined the forms of Western work practices (including HRM, employee involvement, performance management practices) which our survey organisations had adopted, focusing particularly on the changing nature of management and leadership. In general, we found some variation in experience but most organisations had a rhetoric of proactive, enabling and empowering styles of manageent and many were taking practical steps in that direction.Not surprisingly perhaps, the most conservative management cultures were those still in state control, but even here there were signs of change. For example, the parastatal (or 'regie') KPA Canal had recently adopted a new business constitution which committed it to operating on commercial lines even though it remained in the public sector. It was devolving operating authority to its key 
managers and developing performance management systems to encourage managers to act with more autonomy and business awareness. Unfortunately the development of systems seemed to have been uncoupled from the development of culture and the endurance of traditional values threatened to displace desirable new management behaviours. One of the 'empowered' managers told us:

'Suddenly we were required to think and act commercially...it was done with an edict from the top... We want more freedom to manage but we don't have the training and skills and we don't yet trust the system to support new forms of behaviour'.

However, in most of the multi-nationals, foreign-owned and recently founded Romanian organisations in our sample, senior management seemed genuinely committed to modernising their organisations. In most cases the managers were either Romanians who had been Western trained or expatriates. They saw themselves as exemplars of the new management agenda (eg: strategic approach, devolved authority, teamworking, flexibility, participation). Some were deliberately modelling the behaviour they wanted lower level managers to emulate (eg: networking, motivational leadership, transparency, trust building etc). For example, at (SoftSolutions) the founder entrepreneur-manager claimed to use personal example to build a culture of high involvement. Structure was kept to a minimum, informal lateral relations were emphasised, people were valued for their performance, open communications, team involvement and decision making were the new 'commonsense'. At (SoftCo) the CEO spent much of his time practicing a highly facilitative management style: walking around, keeping close to the whispers on the informal networks, identifying and supporting promising projects, building the confidence of his managers in independent action. At (TradeWinds) the top showed its commitment to participative management through consultative machinery and its creation of an open and inclusive culture which rewarded ideas and involved the whole work community in assessing them.

Many of our organisations have been implementing a decentralised, team led management system as a vehicle for participative management and organisational development. A particular focus of development has been the team leader (TL)) role. Attempts have been made to complement the professional skills of senior practitioners with the skills of facilitative leadership. At SteelCo, BrewerLite and Securicarerestructuring of management work and role re-design has gone hand- in- hand with learning and development interventions to build the management capabilities of professionals and seed a culture of high involvement. At SteelCo new systems of manufacturing cells have stimulated team leader facilitation of small production and quality groups; at Securicare a series of teambuilding exercises has been used to help TLs act more democratically and build bridges between organisational levels; at 
BrewerLite the PM system has been used to help teams take ownership of the quality and production process (through radical de-centralisation of budgets; cascading streams of operational data, new spheres of freedom allowed to the group to define its goals and working methods).

Many managers have responded to these opportunities by developing the behavioural strategies and skills which the new management culture seemed to value: overcoming status barriers between grades and levels; experimenting with new 'consulting' styles in facilitating teams of 'knowledge workers'; building flexible communication systems; empowering staff with more authority etc (Securicare).All of these actions are well known strategies of organisational culture change, transformational leadership and strategy routinely used by Western managers in large complex organisations and well written up in the literature (Deal/Kennedy 1982; Bate 1994; Bennis 1980; Kanter 1983; Kotter 1996). Because these models are derived from Western thinking and are usually linked to the dominant professional consensus on effectiveness in HRM (David 1990), they are bracketed here as part of the Anglo-American management model.For older senior staff 'cultural change' often meant a process of denying the values of a lifetime and painfully acquiring the skills of the new age. For younger managers, especially those with less emotional investment in the 'status quo ante' the liberalisation had been personally liberating. The recollections of the Executive Director at CharityHospital who had worked for ten years with the transnational 'SoftDrink' seemed to capture something of the engagement of a new generation of managers with the demands of high performance management:

'I joined 'SoftDrink' in 1991, soon after it arrived in Romania. We needed directive management at the beginning but 'SoftDrink' had good HR systems and within a few years Romanian managers had absorbed the new way of working...Quite soon Romanians were the nationals often chosen by this American giant to set up subsidiaries in other parts of the world...Romanians can adapt to change and can be good managers but they need support at the beginning, mainly helping them to gain confidence. It's a self confidence thing...'

\section{Cultural blocks to the Anglo-American model}

Despite the impetus of new ideologies of management it would be misleading to claim that a paradigm shift in management thinking is happening. Almost all of our organisations experienced 'cultural blocks' or 'resistances' to the participative, pro-active and empowered management which the AngloAmerican model of management implied. The degree of resistance varied considerably, but the factors involved seemed to demonstrate a high degree of consistency cutting across the usual fault lines: state and privately owned business; local and foreign owned business; large and small companies, for 
profit and not for profit; organisations in different sectors of the economy. This consistency of experience between workplaces seemed to lend weight to societal culture and history as the key explanatory variables, even if they were filtered through the mediating membrane of corporate culture.

'Things are getting better as Western ideas of HR come in from the big companies but in much of the public sector things haven't changed much. Many managers, and doctors...those in authority can be very tough minded and rude... They treat people like raw materials...units of production if you like. That's particularly true of the older managers, they expect to make all the decisions and people have to jump to it'.

'Historically the factory manager in Romania was a considerable figure and his word was pretty much law. I remember being in this meeting with a company owner who had been the enterprise manager under Communism. He opened the door and shouted out 'Manolescu', who came running and was cringing like a dog...like Manuel in 'Fawlty Towers'.

Under the old order, management authority had been highly concentrated in the hands of a few people who could wield their authority in quite an arbitrary way without the checks and balances you would expect in the West. Respondents claimed that the management style was often autocratic in this organisation and the main expectation of the workforce was that of quiet obedience. However, although this style may be far from dead in Romania, observers felt that attitudes to authority were changing.

'In the past it seems there was respect for the leader because he was the leader. For the younger people, under forty, your status has to be achieved...you have to earn your respect. It's like Britain in the 50s and 60s the status hierarchy giving way to achievement...'

An middle aged expatriate manager working with Steelco.

In the predominantly private sector companies within our sample, both foreign owned and Romanian, Anglo-American concepts of HRM now hold sway, at least at the level of formal policy and declaratory intent. Flatter, flexible structures, decentralised team management, empowerment and involvement were the strategic 'core values' of the new order. However, to make these values the guiding spirit of the workplace has proved far from easy. Private companies may be more flexible and more open than state run enterprises but they could still seem centralised and formal,at least to Western eyes. In most places, top managers (often expatriates or foreign educated Romanians driving the change process) talked of the uphill struggle involved in encouraging their line reports to break with hierarchical and conservative mindsets and to become more proactive.

For example, at CharityHospital the corporate managers at head office expressed their exasperation at the tendency of their Romanian colleagues to look up for 
direction and their extreme reluctance to use the authority which had been granted to them. One of the English managers in London said:

'We're a long way from real devolution mainly because the senior managers at the hospital (in Romania) seem to expect direction. They know that they have discretion on budgets and policy, but there is still a lot of referring up on small things. Recently I got this memo from the Admin Director saying that a farm wanted to donate a pig and should they accept it? This is not something that should be coming up the line'.

As the expatriate corporate managers tell it, none of the highly professional staff at the hospice seemed either willing or able to take a broad long term view of its future or exercise the leadership needed for difficult decisions on priorities Part of the issue may be that Romanian managers, even at a high level, typically defined their role as short term, operational problem solving rather than strategic and organisational development. They often seemed to see themselves more as 'fixers' of anomalies in a process than creators of an alternative future and could appear ill at ease with problems that were ambiguous and unstructured. This observation is supported by Edwards and Lawrence (2000) who found that Romanian managers often saw their role as mainly about 'fire fighting', 'removing road blocks' and 'meeting short term financial targets'. While they saw their role as now affording far more discretion than in the command economy they tended to respond to the challenge of change rather than drive strategy as a means of bringing about innovation.

Senior managers attributed this expectation of higher direction to a fear of making mistakes and being punished. Often, middle and lower level Romanian managers seemed to lack confidence in their own judgement and preferred to follow instructions rather than solve problems. Equally, managers could seem reluctant to take initiative or to stand out and be held personally accountable for a line of action. Some managers appeared to hide behind procedures, evade responsibility and avoid risk. In the same way, to expatriate eyes, Romanian meetings could seem lengthy and inconclusive without any sense that responsibility was being assigned or accountability for results built into the process. Much organisational process seemed to be a game of procrastination, passing difficult issues around and reacting to events only when the action was unavoidable.

'There is always a lot of deliberate vagueness about what has been decided and what is to be done. I see it as a defence mechanism to avoid blame if anything goes wrong'. A Romanian manager said.

Passivity may also be an expression of a 'wait and see' attitude prevalent at middle management levels. Concerned at the ambiguity around future direction and the costs of making the wrong commitment, managers may deliberately 
maintain a 'strategic ambivalence' until the future order of things becomes clearer.

At KPA Canal middle managers said they were interested in acting more autonomously but were waiting for evidence to accumulate that it was safe to experiment with new behaviours, that success would be rewarded and failure would not attract harsh punishment. Fear engendered hesitation and for good reason. According to some observers Romanian organisations often created 'Potemkin Villages' (1) in which facades of modernity and a rhetoric of reform disguised a reality of stasis and continuity.

'It's a period when a lot of companies- state owned and newly privatised it doesn't matter-are saying that they're innovative and open to new ideas, but a lot of it is a smokescreen to get foreigners to invest in them. Their cultures don't change. Just a year ago we went to Totum (state airline) which prides itself on being 'go ahead' and asked if we could set up a scheme so that foreign passengers could donate their loose change to the hospice before flying home. They refused because they thought this would be a temptation to their staff to steal...But there was such a small chance of that. For me this was an example of an organisation that was cautious, careful and risk averse, just like in the Communist days'

A young charity worker about his experiences with the state owned airline.Building teams also seemed to be particularly difficult in Romanian organisations. Higher level Romanian managers were said to be very conscious of the need to be seen to be in charge and to act as the prime mover in decision making. This 'personality cult' meant that team discussion was often less a decision making process in which people interacted spontaneously, arguments contended and the best ideas were taken forward into policy, than a platform for the senior manager to demonstrate his very personal leadership.

An older Romanian manager at KPA Canal who may have spoken for others in articulating his 'managed' philosophy of group decision making:

'My role is to use my experience to guide my subordinates' ideas along the right channels.'

This was a common observation, often remarked upon by people with cross cultural experience of managing. Here a Romanian manager with experience working overseas comments on the style of senior Romanian colleagues in a business which had recently come into foreign ownership:

'Senior managers often seem to expect to make decisions by themselves after taking soundings. For some, making decisions together with colleagues would be regarded as a threat to their authority...they would feel they had lost face'

This emphasis on the use of personal authority in management was also said to characterise the relations between top Romanian managers and their direct 
reports. Although Western team -based models will be having an impact, we were told that Romanian managers typically liked to brief their direct line subordinates on a one- to- one basis, to give prescriptive instructions and to follow up on an individual basis to see that action had happened.

At levels below the top, norms of hierarchy and deference to higher authority could bedevil teamworking. In professional organisations, the primacy of vertical relationships could fracture vital collaborative working between different disciplines. At CharityHospital, despite its many fine features as a professional community of care, the quality of cross functional teamworking between doctors, nurses, paramedics and general managers was allegedly undermined by the dominance of a vertical, functional axis of loyalty. In organisations which had tried matrix models these had failed for the same reasons (the experience of managers at Clingfit).

CharityHospital also serves to illustrate another important feature of Romanian management culture, as our respondents defined it, the strong emphasis on status and formality. The medical model was entrenched. Higher level professions were loathe to communicate to lower level professions and lower level professions felt inhibited in passing information upwards. This was claimed to be even more pronounced in state hospitals and in much of the state sector.

It was the persistence of an ethos of 'power distance' (Hofstede 1980) in Romanian organisations, apparently based on deference or fear for those in authority, which was most often remarked upon by outsiders. Two senior expatriate managers on their experience in developing their organisation in Romania:

'Five years ago, no one ever looked at the manager when he came onto the floor and his decisions were never challenged. Even now I will get my managers together and ask them what they think of a plan. Silence. They will wait for me to speak first' (A British manager at Clingfit.)

'Until recently you didn't look the manager in the eye...they wouldn't look me in the eye. It's a bit more relaxed now, but they are still very polite... too polite. If I'm walking down a corridor people step back and nod their heads...very deferentially. They don't quite 'doff their caps', but it's like that. They wait for you to go first through the door because you are more important in the system' (An expat manager with Steelco.)

While some of the new hi-tech companies may have escaped this, most organisations in our sample were still trying to overcome an ethos of 'putting things through channels', following the chain of command, observing protocol and formal distinctions of status (eg: in most of our organisations addressing the manager as 'Mr Director, Sir' has only recently been replaced by communication on first name terms). Although respondents said that the climate of openness was improving, there was still an obvious fear of taking 
responsibility, of taking initiative, of being visible. This is well captured in a Romanian saying: 'The tall flower is the one first cut down.' Empowerment was a difficult strategy to implement. Many of the issues of openness and involvement seemed to hinge on trust. Managers often showed themselves reluctant to share information or to participate in discussions. Managers in the favoured position of being able to compare management cultures, noticed that Romanian colleagues were often wary about expressing themselves openly or contributing ideas in meetings, especially if these seemed like criticism or dissent.

An expatriate from Clingfit with many years of experience in Romania:

'Participation is something new in Romania. It's only slowly gaining legitimacy. When a team from Hereford sits down with their Romanian counterparts we expect an open exchange of minds, but we don't get it. They won't say what they feel. Everything is phrased in a diplomatic and guarded way...in an excessively' roundabout way' to our ears'

Reserve and suspicion seemed to cast a long shadow and were not easily banished. A recurring comment by the expats was that Romanian managers in a team are often wary of each other. Especially at the beginning of relationships it was difficult to get full and open discussion. Team dynamics often seemed to involve protecting your position and manoeuvring skilfully around people. One of our respondents described this as 'managing with masks'. A Romanian manager from one of our sample companies (Expressair) who had broad international experience and appeared to us to have good insight:

'It is a trust thing. One element is that Romanian managers often seem to have security and professional respect. You become indispensable. You don't share your knowledge. This is still the dark side of the moon as far as Learning Organisation concepts go.'

Historically, in the atmosphere of fear and uncertainty engendered by Communism, information was a commodity to be hoarded and traded in Romania, a source of status and power. It may be that these habits are only eroded slowly, yet it was alleged that Romanian scepticism about the benefits of collaboration through teamworking goes deeper than this. Again it is best to let our respondents speak through the text. Here is another expatriate (BrewerLite), trying to put his experiences of managing in Romania into words:

'There is a suspicion of colleagues here which goes deep and I don't think I'm just taking about this organisation and its culture. There seems to be a collective assumption that people only do things to get things. People don't advance ideas for the good of the organisation as a whole. Everyone is assumed to have an ulterior motive'

This is very similar to the comments of a perceptive young Romanian manager (SteelCo): 
'There is an assumption that people use the organisation for their own purposes. People are always looking for your inner agenda. So, if the Sales Manager brings up the issue of maternity leave arrangements for the staff, others will think that she is trying to secure some interests of her own'.

What this implies is that building a 'strong culture' of 'trust', 'common values', 'open communications' and 'shared purpose', the usual shibboleths of strategic HRM and change management, may sound particularly hollow in Romania. In fact, given the cynicism about organisational behaviour left over from Communism, these values are more likely to sound like the empty exhortations of Communist planners and ideologues (ie: Stakhanovite (2) exhortations to self sacrifice for the collective) than the strategies of engaged modernisation.

Traditionally, trust has been circumscribed and limited in Romanian organisations. The top has not shown trust in lower levels performing their work without close scrutiny and lower levels have not trusted top managers to think beyond their own interests (Edwards/Lawrence 2000). Although there are instances in our sample where respondents say their organisations have risen above this 'high fear/ low-trust' culture (eg the greenfield, high tech Romanian companies) this seems to be the condition of many Romanian organisations (See Fox, 1974 on the behavioural consequences of low trust relations at work).However, co-existing with this mistrust which seems to go very deep and creates a climate which is highly resistant to open, inclusive Anglo-American HR styles, there may also be an implicit social contract between higher and lower levels. Lower managers and workers have traditionally accepted hierarchical chains of status, tough authoritarian control and downward communication in return for protection, the security of clear direction and the manager as the 'good father figure' (Edwards/Lawrence 2000; Hofstede 1980), the 'red patriarch' or the 'paternal boyar'.

Senior managers from the old order may to have largely taken on this social obligation. It explains the continuing ethos of personal and highly visible leadership (even where it is disconnected from management skills and knowledge). Like the boyars before them, many older Romanian managers seem to believe that they have a duty to lead and also to protect. This may also explain the continuing paternalism of much Romanian management. At a time of global pressures to restructure organisations and shed large numbers of workers, managers in Romania have often tried to preserve jobs and provide a measure of social protection.

Of course, the downside of this social responsibility is that change has not been introduced as fast as outside bodies eg; EU, IMF etc might have wished. It also seems true that economic transformation has been good to the managerial elites in Romania. Unlike many other groups in society, higher managers have emerged stronger and richer from the debris of Communism. They have more powers, freedoms and rewards in the new system than ever before. Top 
managers have often used their advantages for self enrichment through networks, cronyism, nepotism and corruption (Gallagher 2005; Economist 20002006). However, honest and above suspicion the individual senior managers in our sample may be, they are part of a managerial class which merges with a political class popularly seen as lacking in vision and public morality (Gallagher 2005).

'The trouble is many of the elite are above the law and act as if they are. It erodes respect and trust for people in top management because they are seen to all be crooks. That, of course, is an injustice to many, but it is how people think... The worst of it all is that it deprives young people of role models of good leadership... In Romania a successful manager is by definition a rogue'.

An international Romanian businessman living in London.If these are the conditions of the times, they will inevitably have an effect on public trust in management integrity, the transparency of behaviour and the degree of commitment and participation which people lower down the system are prepared to give. They will also draw limits to the real acceptance of HR values which are ultimately founded on a shared order of trust and mutuality.

\section{Culture, history and management}

It seems difficult to explain these themes in management culture unless they are set within the context of national history and culture. Studies eg: Hall (1990); Hofstede (1980); Hickson/Pugh (2001) show that the nature of management and how it is defined varies between societies and dominant cultural norms shape the style of management practised in different places (Hofstede's categories are, of course, a good starting point here). While this is not to imply determinism or deny variations between organisations within the same society in their adoption of various Westernised management styles, the framework of national culture implies a shared experience which influences broad patterns of beliefs and values in management as they cross cut organisations of different kinds (Scarborough 1998).

In any particular case the management culture of an organisation will be an interaction between different spheres of culture- at the sub-organisational, corporate, national even global levels. How societal culture interfaces with corporate culture is complex and the influence may not just be one way. Certainly larger spheres of culture will have a differential effect at the corporate level depending on the type of business, the age of the workforce, the exposure of senior managers to outside influences, organisational values, traditions and ideologies. All the same, because of their all encompassing and amorphous nature, the taken for granted assumptions embedded in the all encompassing framework of national culture will influence impulses and actions in all corners of the economy (Hofstede 1980). 
Here we try to identify some aspects of Romanian history which may explain some of the consistencies of managerial behaviour which transcend corporate differences. What is attempted is an interpretive and explanatory account which does not pretend to be comprehensive but does try to link the specific cultural patterns we have described above to general cultural and historical processes. It also tries to show the cultural contradictions at a time of transition where change jostles uncomfortably with continuity suggesting a very uneven pattern of organisational experience that defies easy generalisation.

\section{The traditional legacy}

For much of its history Romania has been cut off from the mainstream of thinking and cultural development in the West. It's history is also one of authoritarian control from above. Well into the modern period it was a predominantly peasant society in which most people were bound to their lords, or boyars, through feudal obligations. National independence came late to Romania (1870s) so did democracy and arguably the institutions it developed were 'shadow forms' of those in the West (Deletant 2006 conversation). Power has always been held by elites which for the most part have ruled in their own self interest. Whether the elites were foreign overlords or Romanian aristocrats, a mighty and largely autocratic state did little to develop civil society and encourage values of popular participation, local autonomy, transparency or public service. People were largely regarded as subjects rather than citizens (Gallagher 2005).For centuries the predominant themes in most peoples' lives were bureaucracy, coercion and control. Their response was that of obedience, subservience, docility and acceptance (Gallagher 2005; Glenny 1993, 2000). Certain themes are recurring:

- Downward surveillance, punishment induced conformity and submission. It made people frightened of each other, frightened of speaking in public, taking their own decisions or thinking and acting for themselves.

- Absolutism and the arbitrary use of power caused people to be cynical about authority and alienated them from the decision making process.

- Repression concentrated peoples' minds to expect strong leadership to which passivity was the appropriate response in the hope of being left in peace to attend to their traditional practices (the undisturbed farming of peasant smallholdings ).

This is summed up by one of the commentators in an ethnography of Romanian 'voices': 
'The Turks, Austrians and Russians covered us with a complicated maze of rules which they applied with force. As a people we learnt to cringe in the face of authority and avoid public action' (Townson 2005)

The only relatively independent source of authority in this state-managed society, the Orthodox Church, reinforced secular authority by preaching a doctrine of resignation, fatalism and passivity (Deletant 2006). This was the everyday experience of ordinary Romanians for hundreds of years and well within the living memory of older members of the community. These experiences would have been passed on through oral folklore as sagas, myths and didactic narratives to younger generations of Romanians. Although nothing can be claimed with certainty, it does not seem to us far fetched to attribute some of the values of quiescence, mistrust of authority, observable in the modern Romanian workplace, to these historical events which preceded the imposition of Soviet communism. They may explain, at least in part, the fear of 'standing out', of being punished, of thinking critically and fear of participation in decision making. These were the behaviours which have always been proscribed or tightly controlled and often punished in Romania (Seton-Watson 1945).

But the sedimentation of historical experience, laid down generation on generation, may have had more subtle effects. The long continuation of a peasant tradition (even today $50 \%$ of Romanians work on the land and it is the least urbanised of all European countries) means that many who are managers today will have an agrarian background and strong ties to the village. Indeed, many are first generation managers or professionals who were brought up on the farm. Could some of the conservatism, the fear of uncertainty, risk aversion, short time horizons and reluctance to be strategic which seem to characterise the orientation of many modern Romanian managers derive, in part, from the traditional, semi-feudal rhythms of rural life? A strong communal tradition may also be displayed in the primacy of the family and the informal community as a primary source of identity. Where there was such a history of fear and cynicism about official authority it is understandable that people should look to personal relationships for support and advantage and for opportunities to temporarily remove the protective public masks on which survival depended. This 'communal orientation' and mistrust of formal processes may also partly explain the widespread tacit acceptance of 'connections' as criteria for selection which westerners are likely to condemn as 'nepotism' and 'political appointments'.

Finally, a key historical theme in national culture which should be mentioned: the lack of a well established entrepreneurial tradition in Romania. In the preCommunist years, large scale industry (eg: petro-chemicals) was either foreign owned, run by the state or the elite 'camarilla' at court. Local business seems to have been under-capitalised and workshop based. The merchant and small class was very small and lacked status and political profile. Although we are not historians and are open to correction, it seems difficult to believe that 
industrialisation had gone very far in Romania by the time of the Communist takeover. Perhaps the development of a vigorous market economy in the years after 1989 is less a return to Western business values of the inter-war years, more a radical departure from centralised, statist control of industry during the years of Carol II and Communist dictatorship (Gallagher 2005; Deletant conversation 2006)

With Communism the nascent middle class was wiped out, the market economy was extinguished and most private property was appropriated by the state. Until the 90 s there was no opportunity for entrepreneurial values of individual initiative, risk taking, personal responsibility etc to find expression and these philosophies did not form a significant management discourse within Romania until very recent times. Although the disciplines of the market have had an undeniable impact on Romanian management values in subsequent years, management culture is only now becoming influenced by entrepreneurial values (indeed, small business and fledgling entrepreneurism have arguably been undermined by the austerity programmes imposed by international donor organisations like the IMF and World Bank).

\section{Communist 'totalitarianism'}

Although this is not the place to catalogue the many forms of oppression under the 'petty Stalins' of Romania, it is relevant to our theme of workplace culture to say that Communist rule in Romania was amongst the most repressive in the world during the 70s and $80 \mathrm{~s}$ and dominated the lives of everyone who lived there (Simpson 1990; Glenny 2000; Roper 2004). The centuries old authoritarianism was massively augmented by a hard line strain of 'Scientific Socialism' which translated the will of the top to the very lowest levels. The repressive nature of Romanian communism stifled all individual thought, independent spirit and dissent. It demanded complete obedience to the cult of the leader and his grand plans. Just two quotations:

'At the time of Ceausescu's downfall, Romania was a massive police state. People were afraid of everyone they didn't know. If you said something about the authorities they could arrest, beat and kill you' (Simpson 1989)

'Systematisation was Ceausescu's policy to do away with up to half the country's villages and move the rural population into larger centres...His declared aim was to 'wipe out radically the major differences between towns and villages' by herding people together into apartment buildings so that the 'community dominates and controls the individual' and thus produce Romania's 'new socialist man' (Burford)

Fear of denunciation, of losing your job, your house, imprisonment haunted people every day. The mistrust of authority, fear and submissiveness which the 'terror' induced inevitably overlapped into the workplace. 
We have described the Soviet style system of planning imposed onRomania in an earlier paper (Dalton 2006). In terms of our themes just a few facts will suffice. Until 1989 the national economic plan dominated economic life. Central planners determined what goods would be produced, in what quantities and at what prices. In this centralised command and control system targets and quotas were laid down from above. At each level a single manager was held accountable for fulfilling the requirements of the plan. The local enterprise had limited autonomy and was seen as merely one part of the overall system of planning (Maruyama 1993)

Managers were simultaneously immensely powerful and weak. Despite the considerable authority which the manager had over the lives of those reporting to him, both within the factory and outside, Communist managers typically lacked the autonomy and prerogatives of their counterparts in the West. For one thing, managers were closely watched. Despite the principle of single line accountability, the factories were run on lines of collective leadership. A parallel hierarchy of TU and Party cadres monitored management decision making in terms of ideological 'correctness'. This triumvirate leadership massively complicated the management process and embedded an element of paranoia within it which filtered down to the lowest levels of the organisation (Hickson/Pugh 1999).

There were other ways that communist managers were 'in office but not in power'. The centralised structures meant that managers were really administrators, implementing decisions laid down from above (Kilbride 1994). Managers were not expected to take strategic decisions or to innovate. In fact, personal initiative was not encouraged and could be dangerous if it was seen as 'knowing better than the Party' and disrupting work in a system that was primarily focused on numerical targets of production (Edwardes/Lawrence 2000). Although the manager was personally responsible for meeting the Plan targets, all significant decisions had to involve the Party. The powers of managers were also strictly limited. For example, it was extremely difficult for managers to dismiss workers in a system where there was officially no unemployment. Dismissal merely meant that a 'problem employee' was passed on elsewhere and to request transfer was generally seen as testimony of the manager's inability to manage his staff (Edwards/Lawrence 2000; Jankowicz 1994).

Managers were always highly trained specialists, usually with an engineering background, and concerned almost exclusively with production issues. Maintaining smooth process counted for more than cost control or quality improvement, purchasing material was officially out of the managers' hands and no marketing or selling was involved. Managers were appraised as much for their loyalty and political reliability as their performance. But this does not mean that they were necessarily mere functionaries, marionettes dancing on the strings 
of the Party (despite the claims of some of our respondents, see above). Kelemen (1999) emphasises that effective managers did not just rely on the formal structure. They used their networks and bargaining skills to secure a reliable source of supplies, favourable targets, overcome production 'bottlenecks' and deliver the 'impression' of good results which would satisfy the higher levels. Often this required sophisticated political negotiating skills of a high order eg: building up buffer stocks so that each unit was self sufficient; 'quid pro quo' deals with other factories on supplies; deals with the workers on productivity to achieve goals; using the black market; creative manipulation of figures; political deals to get better wages and targets without greater intensity of labour.

One of the managers on our study who had once been a senior manager in the old system:

'The best managers were 'fixers'. They were good negotiators able to use the system for the good of their enterprise. It was all about looking after your people, your factory... and overcoming the deficiencies of the system so that you could deliver something like the results that were required'

This 'getting round the system' seemed to permeate consciousness at every level. 'Baht' ie: exchange of favours, gift giving, fiddling, pilfering from work was the lubricant of the system. In a system of scarcity where goods were hard to get, bribing anyone who is the gatekeeper of resources was a matter of commonsense (Scarborough 1998). The practice permeated everywhere, from the kolkoz manager organising a lavish lunch for local politicians in the hope of securing their support during bargaining with central administration to the gift to a shop assistant to put aside a pair of coveted shoes when they became available (Brenner 1993 for an interesting analysis of the role of illicit practices in maintaining the system).

Perhaps unsurprisingly given the engineering background of managers and the importance of production values, the dominant system of work under Communism was 'Fordist-Taylorist'. Management was largely defined as the practice of a techno-rational process, based onscientific management principles concerned with productivity through the application of 'best method'. The 'human factor' at work was neglected. Workers tended to be treated as automata, tied to the rhythm of machine-paced production through authoritarian management and tight labour discipline (Lawrence/Edwards 2000).

As in wider society, the emphasis in the workplace was on obedience, hierarchy and control. Enterprises had social and political as well as economic roles and the tight surveillance in everyday life found its counterpart in the factory. The HR departments were extensions of the secret police concerned to watch for signs of ideological disloyalty or mistakes at work which might be interpreted as 'industrial sabotage by counter-revolutionaries' (an elastic charge which could also be applied to politically suspect or 'incompetent' managers ), earning them 
a period of hard labour helping to build the Black Sea Canal (Deletant 2006; Gallagher 2005).

Although the workplace culture under Communism seems to have been harsh, it was also paternalistic. Factories were responsible for child care, welfare, health services, housing and some general services like shops. To a degree inconceivable to the West the workplace was at the heart of the local community. It was also the conduit through which the state asserted its central importance in the lives of its citizens.

Communism has added another layer to the historical legacy which shapes behaviour in Romania. Combining with earlier influences, it is surely a key to understanding the mistrust of authority, the reserve and lack of openness, the 'corruption' and fear of dissent which we have identified. It also explains the hierarchical style of many managers, their lack of initiative or concern to innovate, their highly operational, technical definitions of the management process. On the positive side, a residual paternalistic tradition may shape a socially responsible transition to capitalism and the 'flexible' behaviour required to operate effectively under the old command system may translate into the entrepreneurism needed by managers in the uncertainties of a fluid new order.

Fifty years of a system as totalising in its ideology and control as the one put in place by Ceausescu leaves deep psychological scars and is not easily erased from memory, even for those who were children at the time.

'The reality is that Communism persists in the way people behave, the looks in their faces and the way they think...Ceausescu is in everyone of us and we haven't killed him yet...will we ever?' (An observer of the Romanian revolution in 1989 quoted in Simpson 1990).

An acute observation at the time, but does it still capture something of the Romanian psyche as the country joins the West?

\section{The post-Communist period}

Seventeen years have gone by since the fall of Ceausescu Although seventeen years is a long time in the span of a single life, it is not so long in historical time. For Romania it has been a period of great economic uncertainty and political turmoil. It has been a time of re-structuring, the release of new economic forces and political pluralism which may turn Romania into a Western style, liberal capitalist state. However, there are also continuities with the past which draw cultural limits to the pace of modernisation.

After 1989, de-regulation, privatisation and the transfer of state enterprises to the private sector moved the economy to a more market based economy. Organisations became independent entities no longer tied in to a planned system. They had to shift their focus from production to marketing. They also had to 
ditch their social responsibilities such as housing, medical care etc because they were seen as a drag on profitability. The re-structuring had to be done without a road map to guide the architects of change required to make the unprecedented shift from a planned to a market economy.

Our Romanian respondents confirmed that the fall of Communism had the effect of 'shaking up' the ranks of Romanian managers. A Romanian manager who, in his early 30s, found a new job with Coca Cola soon after the Revolution:

'You could feel things were coming to a head in the late 80s. It was in the air. People couldn't take any more. Many managers were bursting to show that they could manage...and there was some national pride here. We wanted to show we could be as good as the people in the West if we were given a chance'

However the problems of adaptation have been considerable. Managershave had to learn new disciplines such as marketing, sales, financial management and HRM. Administering a 'steady state' system was replaced with a need for capabilities in risk taking, creativity, innovation, tolerance of ambiguity, independent thinking and market making, all alien to the experience of those who had worked under communism. Some of the older managers and those unable to adjust seem to have been marginalised or forced to take early retirement. Others became 'born again' managers able to grasp the new freedoms and act as the pro-active managers which they had long hoped to be under the old order.The conditions of the times are now very uncertain for managers.

As we have seen, managers are developing new styles of managing at very different rates, in different sectors of the economy. Although the climate in private companies may be more encouraging of liberal, humanised management, as our data suggests, everywhere there are issues of formality, centralisation, lack of trust and openness which inhibit development.

To contextualise these issues within a larger explanatory framework is difficult because the patterns are still unfolding. However, here are some of the trends in societal culture which seemed important to us in understanding aspects of the managerial culture which we have already identified.

We have already examined the 'democratic in Romanian society as a constraint on the emergence of a new participative management culture. Despite the claims, it is difficult to believe that democracy has now become consolidated and there is a strong civic culture of intermediary organisations between the state and the individual. Democracy seems fragile. What may exist is a form of political corporatism in which the dominant party controls government machinery through a network of patronage. Even in coalition with other parties, even in opposition, it has been argued that the entrenched power of this dominant party continues to shape the political agenda. There are also claims of a 'state within a state', that elements of the old order continue to wield 'hidden 
power' beneath a democratic façade (Gallagher 2005). Whether this power is on the wane and pluralism and transparency are on the rise may be a matter of debate.

It may be that the continuation of an authoritarian tradition at the political level conditions everyday life as far down as the workplace. Without a model of democracy to guide them, building democracy in the workplace is likely to be massively difficult for even the most motivated and democratic manager.Another theme is the alleged polarisation of the managerial class in Romania. In the period after Communism, members of the higher elite eg exkolkoz managers, factory managers and party politicians, formed a close association with the ministries for which they worked. An oligarchy of the new rich, often benefiting from state credits, subsidies, closed privatisation issues and contracts grew up ('Nomenklatura capitalism') (5). Higher managers as a class have done well out of the debris of Communism. They have more powers, freedoms and rewards in the new system than ever before. In terms of popular perception they are seen as part of a political class which is widely seen as lacking in vision, in integrity, self serving and unscrupulous (Edwards/Lawrence 2000; Gallagher 2005). The condition of middle level managers and those lower down and without insider networks has been far less secure.

This may partly account for the widespread mistrust of authority, including management authority, and the poor reputation of those in leadership positions in many ex-state organisations. Two arresting comments by Romanian managers very differently placed in the social order:

'A problem for Romanians is that we don't have models of good democratic leadership. Leaders here are always presented as tough and strong by the media but these may be the wrong values.. and then there's the problem that leaders are generally seen as crooks because of all that's gone on since Communism'. (A Romanian management educator)

'Most managers under 40 only have vague memories of the old power and state structure...but they remember how big business started in Romania in the 90sthrough insider relations, short run hits, opportunism and political affiliation...The big fishes are usually politically involved and behave like sharks around traces of blood'. (A young Romanian entrepreneur)

The survival of large sections of the old communist elite, now in business roles, may have acted as a block to change. An interesting feature of the Romanian economy is the relatively slow transformation of the economy in the 90 s. In a study of senior managers in Transylvania in 1997, Catana (1997) found considerable resistance to change. Managers were held back by the desire for stability, lack of management skills and uncertainty but also because they were often reluctant to offend communal obligations. Acting with a sense of social responsibility may be the distinguishing feature of a new form of management 
from which many Western organisations, post-Enron, may learn. However, respect for communal values may also have constrained the implementation of policies which are arguably economically necessary (in the world as it is) if Romania is to become a liberal economy and satisfy EU development criteria, even if they have negative social consequences (eg unemployment). A rhetoric of 'community' may also be used to justify the continuation of aspects of the former system such as paternalism, nepotism, cronyism and appointments on political grounds.

For most of the period of Social Democratic government when there was little pressure for 'root and branch' reform from the op, Romanian management often seemed to procrastinate over change (Economist 2000-2006) A political climate concerned about social unrest arising from economic dislocation, traditional time horizons, a culture of administrative incrementalism, the lack of an entrepreneurial spirit and the reactive attitude of managers (all aspects of national culture we have identified above) may have combined to inhibit change in many Romanian companies. As our research shows, these are issues which are only now being addressed. Where attempts at 'turnaround' have happened they may have been prompted more by the need for survival than a restructuring plan. The view of one of the 'new class' of young, very bright, Romanian businessmen:

'Up to the year 2000 the economy was still largely dominated by the state which hoped to make slight adjustments but keep things generally intact. Romanian managers took a 'wait and see' approach...Companies reorganised themselves only when the knife was at their throats and when they were in danger of losing clients, losing their grip on activity and resources'.

But this is changing very fast. In recent times the government has been trying to rapidly modernise the economy to gain EU accession and the old certainties of subsidies, tax relief and centralised investment are ending. Managers in all parts of the economy are now under real market-driven pressure to deliver results. These may be the conditions for 'unfreezing' which are needed for widespread recognition that the traditional patterns of management no longer work and radical new approaches may be required.

The role of foreign owned, especially multi-national companies, as exemplars of more flexibility, openness and democratic management, appears to be an important factor in cultural shift at the enterprise level. It seems from our research that new knowledge and managerial thinking are filtering into the mainstream of management thinking through the backdoor of foreign owned subsidiaries. As these practices are adopted more widely - through foreign acquisition, 'management buy out', 'joint ventures' etc - and begin to impact on increasingly wider circles of management culture so new styles of managing (eg: risk taking, pro-active, involving, results driven etc) may build to 'critical mass' and have a real impact on everyday practice. 
As a final dimension, which may explain some of the variation in management values and behaviour, it has been suggested that a major distinction between managers may be inter-generational. While those who had adult experience of managing under Communism may bear the imprint of that experience in their passivity, caution and conservatism, younger managers, who carry less 'mental baggage' from the past, are more likely to be innovative, flexible and experimental. Certainly, this is the view of multi-nationals who prefer to recruit those 'uncontaminated by the past', as one of our respondents memorably described them. As the younger generation comes to power it may be that many of the cultural blocks we have identified will fade in significance. Certainly in the two new start-up companies which we investigated the management atmosphere was far more open and expressive than in other organisations. This is borne out by reports from other entrepreneurial hi-tech companies offering software and engineering services which are attracting international investment (Ewing et al 2005). If this presages the new Romanian management then it will be far more enabling, team based and empowering than its antecedents. However, it is to be hoped that management modernisation and the embracement of Westernisation will not be at the expense of what was valuable in the old tradition, not least that sense of social responsibility, often wrongly defined as paternalism, with which Anglo-Americanism may soon have to re-engage.

It is evident that intense cultural experiences such as those which form the historical record of Romania are not easily overcome.

It is this residual hold of history which makes cultural change at the level of the organisation so difficult to undertake and the outcome always compromised by the legacy of the past. However, perhaps the best hope lies with enlightened Romanian modernisers who understand that the past was not all bad and the future does not require that it be reviled or more dangerously forgotten as an embarrassment. Cultural amnesia means there can be no dialogues and no lessons can be drawn to serve in the development of the future.

\section{A typology of Romanian managers}

Drawing on the field data and the literature perhaps it is possible to conceptualise the contrasts in management culture in the form of a 'typology' of management orientations to be found in modern day Romania:

a) Traditional Managers: These are largely unreformed managers who behave according to the administrative rules of hierarchy, procedure, bureaucracy and process. These may be largely found in the state managed enterprises. Not yet fully committed to the changes which all organisations need to address in current conditions (eg; upgrading quality, raising standards of marketing, empowering people and selling to new customers) these can appear like 'yesterday's men'. 
b) Entrepreneurial managers: These are managers who are committed to entrepreneurial activity. They are leading new start enterprises or engaged in innovation and restructuring in more established companies to achieve economic success. They have flexible, market-led attitudes. Some will be from the old order who were able to transfer their skills of 'playing the system' under communism to new conditions, others will come from a new class of thrusting young owner/entrepreneurs or 'spiralist' managers.

c) Paternalist managers: These are the managers who are attempting to introduce change so that their enterprises become more effective in market terms yet are still led by social values eg: recognising communal obligations; maintaining employment where they can; addressing social and human issues. This group could act as a block to inexorable economic change. However from it the model of a new kind of manager- the participative, innovating reformer concerned to build an ethic of enlightened 'social management' may eventually emerge.

d) Missionary managers: These are the expat managers from the West investing in Romania because of its low cost base and good technical skills, who are often the torchbearers for a new management culture. They can be part of the solution if they act as agents for knowledge transfer, facilitators of experimentation and exemplars for modernisation. However, they can also be part of the problem if they expect techniques which work in London to work equally well in Bucharest without interpretation and adaptation.

e) Self seeking managers: These are the managers who recognise the new opportunities in a de-regulating economy which gives special opportunities to insiders to enrich themselves through privatisation and favoured business relationships etc. These are the 'nomenklatura managers' who know how to use their networks to make short term gains. They are also the 'nouveau riches' and crime linked businessmen who can use the new uncertainties for their own advantage.

\section{Conclusion}

What the foregoing hopefully suggests is that management culture in Romania is in a period of transition. There is a Romanian saying: 'Brains take a long time to thaw out after a hard winter'. The brains of Romanian managers are still thawing to the possibilities of new ways of managing. Management culture is shifting from the homogeneity of communism to the heterogeneity of the market. Shadows of the old 'Stalinist' management, of autocratic-paternalism, of centralism and 'scientific management' in the workplace still linger. But the liberalisation of the economy is creating new social groupings whose interests are tied to economic success through the market. Organisations are adapting to the demands of external forces like EU in order to survive. Multi-national 
companies are acting as vehicles for new technology, knowledge and management practice. Romanian managers themselves are recognising that old rules no longer apply and are reaching for new ways of doing management. Historically Romanians have adopted ideas from outside- Turkish, Austrian, Russian- and these have been empty forms because they do not chime with local culture. It is to be hoped that on this occasion, managers will not take on AngloAmerican ideas of managing without critically assessing their value and infusing them with the lessons of managing from their own history. The greatest danger is that Romania develops a collective amnesia about its past in the rush to modernise and be accepted as a Western country.

\section{Epilogue}

It is the writers' hope that this article suggests that it is not enough for the Western businessman to 'think global, act local'. It is also important that they think about the local and know something about it. Romania is now a member of the EU and other countries on the Eastern marchlands of Europe will soon join. To Western business men these are often unfamiliar places and local behaviour can appear enigmatic. Understanding cross cultural variables and especially the interaction between national culture and organisational processes is essential for conducting business in a way which is contextually appropriate.As this study of Romania suggests, effectiveness requires a critical appreciation of the historical legacy as it continues to express itself in the micro-processes of every day organisational behaviour.

\section{Acknowledgements}

We would like to thank John Bowden, Dr Alex Weich, Professor Linda Clarke (of Westminster Business School); Professor Gallagher (Bradford University); Professor Deletant (London School of Slavonic Studies) and our special London advisers on Romania, Ana and Irina.

\section{Appendix}

\section{HOFSTEDE'S MODEL OF NATIONAL CULTURAL DIFFERENCES}

Although this research takes a more interactive view of culture than Hofstede, his classic definitions of cultural dimension are a useful starting point for considering variables of national culture.

\section{- Power Distance}

Power distance is the extent to which inequalities of power within a country (and in the organisation) is distributed unequally and that is accepted as legitimate. Romania is a 'high power distance' society (87)*. In comparison the 
UK would be a relatively low PD country (35). These values seem consistent with our findings on hierarchy and authoritarianism at work.

- Individualism/Collectivism

Individualism/Collectivism

- Masculinity/Femininity

This dimension attempts to define how far 'masculinist' values (according to Hofstede: assertiveness; toughness; competitive; materialistic) dominate as opposed to 'feminine' ones (modesty; passivity; low assertiveness etc). Although this is quite a vague category, the relatively low rating on 'masculinity' (40), is consistent with our findings on deference and passivity at work. The UK comparison is much higher (63).

- Uncertainty Avoidance

This is defined as the extent to which members of the culture typical feel threatened by ambiguity and are reluctant to take risks. Romania scores high on uncertainty avoidance (90) which may be largely a reflection of the recent experience of Communism. By comparison the UK scores quite low (36).

$* * * * *$

Although it is dangerous to read too much into Hofstede's categories which have often been criticised for their superficiality, abstraction and vagueness, they do offer some corroborative support for our results.

NB: $*=$ out of 100 .

\section{References}

Bate, (1994): Strategies for Cultural Change, Butterworth Heinemann.

Bennis, W. (1989): On Becoming a Leader; London: Business Books.

Beardwel1/Holden, L. (2001): Human Resource Management, Prentice Hall.

Brenner, R. (1993): The Long Road to Serfdom and How to Shorten It in: Maruyama, Mopcit.

Brewster, C./Hegewisch, A. (eds): Human Resource Management in Europe, Routledge.

Brewster, C./Mayrhofer, W. (2004): Human Resource Management in Europe: Evidence of Convergence? Palgrave.

Brown, A. (1998): Organisational Culture, Prentice Hall.

Burford, T./Richardson, D. (2001): The Rough Guide to Romania, Penguin.

Catana, D./Catana, A./Finlay, J. (1999): Managerial Resistance to Change: Romania's Quest for a Market Economy, JEEMS, Volume 4, Number 2. 
Dalton, K. (2006): Changing Patterns of HRM in the Romanian Organisation in: The International Journal of Knowledge, Culture and Change Management, Volume 5, Number 8.

Dalton, M. (1959): Men Who Manage, Wiley.

Deal, T./Kennedy, A. (1988): Corporate Cultures: The Rites and Rituals of Corporate Life, Penguin.

Deletant, D.: (forthcoming book) Culture in Romania during the Communist period.

Economist 2000-2006: (numerous short news articles on Romania and eastern Europe during that period).

Easterby-Smith (ed.) (1992): Management Research, Open University.

Edwardes, V./Lawrence, P. (2000): Management in Eastern Europe, Palgrave.

Fox, A. (1974): Beyond Contract: Work, Power and Trust Relations, Faber and Faber.

Gallagher, T. (2005): Theft of a Nation, Hurst and Co.

Glenny, M. (1993): The Re-birth of History, Penguin.

Glenny, M. (2000): The Balkans, Granta Books.

Guest, D. (1990): Human Resource Management and the American Dream, Journal of Management Studies, 27, 4, 378-97.

Hall, E./Hall, M. (1990): Understanding Cultural Differences, Inter-cultural Press.

Hegewisch, A./Brewster, C. (1993): European Developments in HRM, Routledge.

Hickson/Pugh, D. (1995): Management Worldwide, Chp 7,10 Penguin Books.

Hofstede, G. (1980) : Culture's Consequences, Sage.

Hofstede, G. (1991): Cultures and Organisations: Software of the Mind, McGraw Hill.

Hofstede, G. (1993): Cultural Construct in Management Theories, Academy of Management Executive, Feb 1993

Holbeche, L. (2005): High Performance Organisations, Wiley.

Huselid, M. (1995): The impact of Human Resource Management practices on turnover, productivity and corporate financial performance, Academy of Management Journal, $38,3,635-72$.

Jankowicz (1994): Parcels from Abroad: The Transfer of Meaning to Eastern Europe, Journal of European Business Education, 3, 2.

Kanter, R. (1983): The Change Masters, Simon and Schuster.

Kotter, J. (1996): Leading Change, HBR

Kelemen, M. (1999): The Myth of Restructuring, Competent Managers and Transition: A Romanian Tale, British Journal of Management, 10, 199-208

Kelemen, M./Kostera, M. (2002): Critical Management Research in Eastern Europe, Palgrave.

Kilbride, P. (1994): Human Resource Management in Europe, Routledge.

Kluckholn, F./Strodtbeck, F. (1961): Variations in Value Orientations, Peterson. 
Laurent, A. (1983): The cultural diversity of Western conceptions of management, International Studies of Management and Organisation, 13, 1-2, 75-96.

Maruyama, M. (1993): Management Reform in Eastern and Central Europe, Dartmouth Publishing.

Mole J. (2003): Mind your Manners, Nichols Brealey.

Regan, G. (2002): Historical Blinders, Andre Deutsch.

Ritzer, G. (1998): The McDonaldisation of Society, Sage.

Roper, S. (2000): Romania: the Unfinished Revolution, Routledge.

Scarborough, J. (1998): The Origins of Cultural Differences and their Impact on Management.

Schein, E. (1985): Organisational Culture and Leadership, Jossey-Bass.

Schneider, S./Barsoux, Jean-Louis (2003): Managing Across Cultures, Prentice Hall.

Seton Watson (1945): A History of Eastern Europe, OUP.

Silverman, D. (1993): Interpreting Qualitative Data: Methods for Analysing Talk, Text and Interaction, London, Sage.

Simpson, J. (1990): Despatches from the Barricades, Hutchinson.

Sparrow, P./Hiltrop, J. (1994): European HRM in Transition, Prentice Hal.

Tayeb, M. (1988): Organisations and National Culture, Sage.

Townson, A. (2005): We Wait for You: Unheard Voices from Post-Communist Romania, Hamilton Books.

Trompenaars, F./Hampden-Turner, C. (1993): Riding the Waves of Culture, Nicholas Brealey Publishing.

Watson, T. (1994): In Search of Management: Culture, Chaos and Control in Managerial Work, Routledge. 